\title{
Peramalan Menggunakan Model Generalized Space Time Autoregressive (GSTAR) untuk Indeks Harga Konsumen di Empat Kota Provinsi Sulawesi Selatan
}

\author{
Muhammad Alkifar Masdin ${ }^{1}$, Nur'eni $^{2}$, Desy Lusiyanti ${ }^{3}$ \\ ${ }^{1,2}$ Program Studi Statistika, ${ }^{3}$ Program Studi Matematika \\ Jurusan Matematika, Fakultas MIPA, Universitas Tadulako \\ ${ }^{1}$ alkifarmasdinmuhammad@gmail.com, ${ }^{2}$ eniocy@yahoo.com, \\ ${ }^{3}$ desylusiyanti@gmail.com
}

\begin{abstract}
Abstrak
Indeks Harga Konsumen (IHK) adalah indeks yang menghitung rata-rata perubahan harga dari suatu paket barang dan jasa yang dikonsumsi oleh rumah tangga dalam kurun waktu tertentu. Data IHK merupakan data runtun waktu, sehingga dapat dimodelkan menggunakan analisis time series. Dari beberapa aplikasi, data runtun waktu dicatat secara bersamaan di sejumlah lokasi yang menghasilkan runtun waktu spasial. Penelitian ini menggunakan metode Generalized Space Time Autoregressive (GSTAR). Penelitian ini bertujuan untuk mendapatkan model GSTAR terbaik dan hasil peramalan untuk data Indeks Harga Konsumen (IHK) di Kota Watampone, Kota Makassar, Kota Pare-Pare dan Kota Palopo. Hasil yang diperoleh dalam penelitian ini ialah model GSTARI $(1 ; 1 ; 1)$ menggunakan bobot lokasi seragam karena menghasilkan residual bobot lokasi yang memenuhi asumsi white noise dengan nilai RMSE 10,63. Hasil ramalan yang diperoleh pada bulan Januari dan Februari berbeda dengan data aktual, hal ini dikarenakan adanya perbedaan tahun dasar yang diberlakukan mulai Januari 2014. Mulai Maret 2014, hasil ramalan data IHK empat kota di Provinsi Sulawesi Selatan relatif stabil dan mendekati nilai data aktual.

Kata kunci: Indeks Harga Konsumen, Runtun Waktu, GSTAR, White Noise, RMSE, Ramalan.

Abstract

The Consumer Price Index (CPI) is an index that calculates the average change in price of a set of goods and services consumed by households within a certain time. CPI data is time series data, so it can be modeled by using time series analysis. In several applications, time series data are recorded simultaneously in a number of locations that produce spatial time series. This study uses the Generalized Space Time Autoregressive (GSTAR). This study aims to obtain the best GSTAR model and the forecasting results of Consumer Price Index (CPI) data in Watampone City, Makassar City, Pare-Pare City and Palopo City. The results obtained in this study is GSTARI $(1 ; 1 ; 1)$ using a uniform location weight because it produces residual location weights that fulfill the white noise assumption with RMSE value of 10,63. Forecast results obtained in January and February different from the actual data, this is due to differences in base year effect starting January 2014. Starting March 2014, the results of the CPI forecast four cities in South Sulawesi are relatively stable and close to the actual data value.

Keywords : Consumer Price Index, Time Series, GSTAR, White Noise, RMSE, Forecast.
\end{abstract}

2000 Mathematics Subject Classification: 37M10

Received: 2018-03-02, accepted: 2018-05-09. 


\section{Pendahuluan}

Inflasi didefinisikan sebagai kenaikan harga barang dan jasa yang berlangsung secara terus-menerus (BPS [1]). Inflasi merupakan permasalahan ekonomi yang tidak bisa diabaikan, karena dapat menimbulkan dampak yang sangat luas, oleh karena itu inflasi sering menjadi target kebijakan pemerintah. Provinsi Sulawesi Selatan sebagai provinsi yang berperan penting sebagai pintu gerbang Kawasan Timur Indonesia, memiliki empat kota penghitung inflasi yang bisa memberikan gambaran adanya pergerakan perubahan harga di Provinsi Sulawesi Selatan. Berdasarkan data BPS [2], pada tahun 2014 untuk inflasi empat kota yang ada di Provinsi Sulawesi Selatan, Kota Pare-Pare memegang Inflasi tertinggi diantara empat kota lainnya yakni 9,38 \%, disusul oleh Kota Palopo 8,95 \%, Kota Makassar 8,51 \% dan Kota Watampone 8,22 \%. Dari empat kota yang ada di Provinsi Sulawesi Selatan, inflasi Kota Watampone berada di bawah realisasi inflasi nasional yang sebesar $8,4 \%$, tiga kota sisanya masih berada di atas realisasi inflasi nasional yang sebesar $8,4 \%$.

Mengingat bahwa sebagian besar inflasi kota yang ada di Provinsi Sulawesi Selatan masih berada di atas realisasi inflasi nasional, maka dibutuhkan indikator yang digunakan untuk mengukur tingkat inflasi. Salah satu indikator yang sering digunakan untuk mengukur tingkat inflasi adalah Indeks Harga Konsumen (IHK)(Kemenko Perekonomian [3]). IHK menggambarkan rata-rata perubahan harga dari suatu paket barang dan jasa yang dikonsumsi oleh rumah tangga dalam kurun waktu tertentu (BPS [1]). Perkembangan IHK keempat kota yang ada di Provinsi Sulawesi Selatan memungkinkan tidak hanya mengandung keterkaitan dengan kejadian pada waktu-waktu sebelumnya, tetapi juga mempunyai keterkaitan dengan lokasi atau tempat yang lain dalam memenuhi kebutuhan barang dan jasa.

Data IHK merupakan data runtun waktu (time series), sehingga dapat dimodelkan dengan menggunakan metode analisis time series (Hapsari [4]). Dalam banyak aplikasi, beberapa runtun waktu dicatat secara bersamaan di sejumlah lokasi yang menghasilkan runtun waktu spasial (space time), yaitu data tidak hanya dipengaruhi oleh waktu-waktu sebelumnya, tetapi juga memiliki keterkaitan antara satu lokasi dengan lokasi lainnya (Ardianto [5]). Dalam penelitian ini akan diterapkan metode Generalized Space Time Autoregressive (GSTAR) untuk pemodelan data IHK empat kota di Provinsi Sulawesi Selatan menggunakan empat pembobot lokasi, yaitu bobot lokasi seragam, biner, invers jarak dan normalisasi korelasi silang, karena secara umum empat bobot lokasi tersebut yang sering digunakan dalam metode GSTAR dan dari keempat bobot tersebut akan dilihat bobot mana yang menghasilkan model GSTAR dengan kesalahan peramalan terkecil.

\section{Model Generalized Space Time Autoregressive (GSTAR)}

Model GSTAR adalah salah satu model yang banyak digunakan untuk memodelkan dan meramalkan data deret waktu dan lokasi. Model GSTAR merupakan generalisasi dari model Space-Time Autoregressive (STAR). Perbedaan yang mendasar antara model GSTAR dengan model STAR terletak pada pengasumsian parameternya. Model STAR mengasumsikan lokasilokasi yang digunakan dalam penelitian adalah sama, sehingga model ini hanya dapat diterapkan pada lokasi yang bersifat seragam. Sedangkan pada model GSTAR terdapat asumsi yang menyatakan lokasi-lokasi penelitian yang bersifat heterogen, Keheterogenan lokasi dicirikan melalui karakteristik lokasi yang dikuantifikasi melalui matriks bobot lokasi (Ruchjana [6]).

Menurut Borovkova et al, [7] model GSTAR dari orde autoregressive $\mathrm{p}$ dengan orde spasial $\lambda_{1}, \lambda_{2}, \lambda_{p}$, GSTAR $\left(p ; \lambda_{1}, \lambda_{2}, \lambda_{p}\right)$ dalam notasi matriks dapat ditulis sebagai berikut:

$$
Z(t)=\sum_{s=1}^{p}\left[\phi_{s 0}+\sum_{k=1}^{\lambda s} \phi_{s k} W^{(k)}\right] Z(t-s)+e(t)
$$


dengan :

$Z(t)$ : vektor acak ukuran $(N \times 1)$ pada waktu $t$, yaitu $Z(t)=\left[Z_{1}(t) Z_{2}(t) Z_{N}(t)\right]$.

$\lambda s \quad:$ orde spasial pada autoregressive $k e-s$

$\phi_{s 0} \quad$ : diagonal $\left(\phi_{s} 0^{(1)},, \phi_{s} 0^{(N)}\right)$ yang merupakan matriks parameter waktu, $s=1,2,, p$

$\phi_{s k} \quad:$ diagonal $\left(\phi_{s} k^{(1)}, \phi_{s} k^{(N)}\right)$ merupakan matriks parameter spasial, $k=1,2, \lambda s$

$W^{(k)}$ : matriks bobot ukuran $(N \times N)$ pada lag spasial $k e-k$, nilai pembobot yangdipilih memenuhi syarat $w_{i} i^{(k)}=0$ dan $\sum_{i \neq j} w_{i j}^{(k)}=1$ untuki $=1,2,, N$

$e(t) \quad$ : white noise dengan vektor mean 0 dan matriks varian kovarian $\sigma^{2} I$

\section{Metode Penelitian}

Data yang digunakan dalam penelitian ini adalah data sekunder yang berasal dari publikasi Badan Pusat Statistik. Penelitian ini menggunakan data IHK empat kota di Provinsi Sulawesi Selatan yang meliputi Kota Watampone, Kota Makassar, Kota Pare-Pare dan Kota Palopo. Data IHK diambil pada periode Juni 2008 hingga Desember 2014. Data tersebut dibagi menjadi dua bagian yaitu data in sample (pendugaan model) mulai Juni 2008 hingga Desember 2013 dan data out sample (validasi model) mulai Januari 2014 hingga Desember 2014. Terdapat Empat variabel yang digunakan dalam penelitian ini, yaitu:

(1) Z1(t) : Indeks Harga Konsumen Kota Watampone

(2) Z2(t) : Indeks Harga Konsumen Kota Makassar

(3) Z3(t) : Indeks Harga Konsumen Kota Pare-Pare

(4) Z4(t) : Indeks Harga Konsumen Kota Palopo

Adapun Analisis data dalam penelitian ini dilakukan dengan menggunakan prosedur tiga tahap Box-Jenkins untuk model Generalized Space Time Autoregressive. Berikut adalah tahapan yang dilakukan untuk menganalisis data dalam penelitian ini:

(1) Megumpukan data deret waktu dan lokasi yang akan digunakan dalam penelitian.

(2) Mengecek kestasioneritas data dengan melihat Plot MACF.

(3) Melakukan pengujian keheterogenan lokasi menggunakan indeks gini.

(4) Menentukan orde waktu dari model GSTAR yang sesuai berdasarkan hasil identifikasi pada model VAR dengan menggunakan MACF, MPACF, dan AIC minimum.

(5) Menentukan bobot lokasi yang digunakan pada model GSTAR.

(6) Melakukan estimasi parameter model GSTAR untuk masing-masing bobot lokasi.

(7) Melakukan pengujian asumsi residual.

(8) Menentukan model GSTAR terbaik berdasarkan nilai RMSE terkecil.

(9) Melakukan peramalan data deret waktu dan lokasi dari model terbaik.

\section{Hasil dan Pembahasan}

3.1. Hasil. Analisis deskriptif digunakan untuk memberikan gambaran umum data Indeks Harga Konsumen (IHK) di empat kota yang ada di Provinsi Sulawesi Selatan, yakni Kota Watampone, Kota Makassar, Kota Pare-Pare dan Kota Palopo. Data yang dianalisis dalam penelitian ini adalah data Indeks Harga Konsumen dari bulan Juni 2008 hingga Desember 2013.

Pada Gambar 1 secara umum pola data IHK keempat Kota di Provinsi Sulawesi Selatan relatif sama yang cenderung naik secara terus-menerus, menunjukkan efek saling berkaitan antar keempat kota tersebut. Kecenderungan IHK yang saling berkaitan dapat dilihat dari nilai korelasi antar kota yang sangat tinggi pada Tabel 1 berikut:

Tabel 1 menjelaskan bahwa IHK empat kota yang ada di Provinsi Sulawesi Selatan yaitu Kota Watampone, Kota Makassar, Kota Pare-Pare dan Kota Palopo untuk waktu yang bersesuaian memiliki korelasi yang signifikan, terlihat dari nilai p-Value yang lebih kecil dari $5 \%$ dan keterkaitan data IHK antarlokasi sangat tinggi, hal ini terlihat dari nilai korelasi dari data IHK pada keempat kota tersebut mendekati 1, sehingga pemodelan secara multivariat dapat diterapkan pada data ini. 


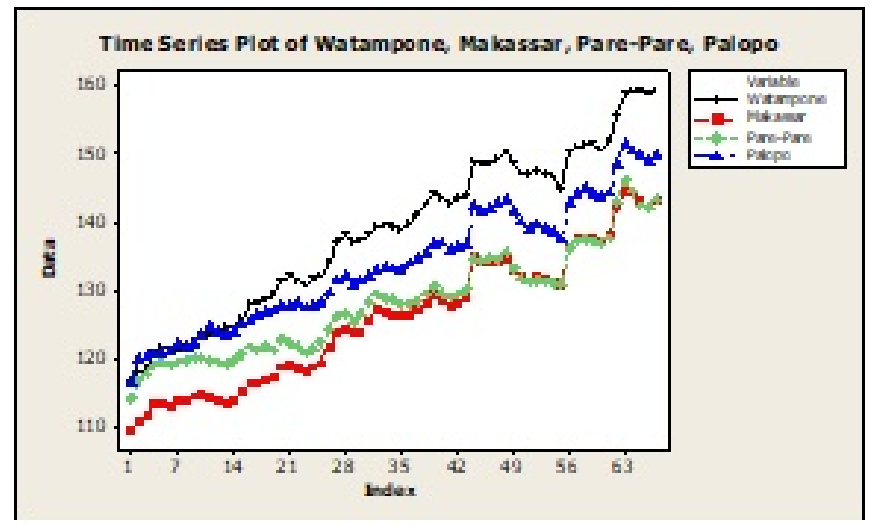

Gambar 1. Plot Time Series Data IHK empat Kota di Provinsi Sulawesi Selatan Secara Bersama-sama

TABEL 1. Nilai Korelasi Data IHK empat Kota di Provinsi Sulawesi Selatan

\begin{tabular}{ccccc}
\hline Lokasi & Watampone & Makassar & Pare-Pare & Palopo \\
\hline Watampone P-Value & 10,000 & & & \\
Makassar P-Value & 10,992 & 10,000 & & \\
Pare-Pare P-Value & $0,9770,000^{*}$ & $0,9930,000^{*}$ & 10,000 & \\
Palopo P-Value & $0,9940,000^{*}$ & $0,9950,000^{*}$ & $0,9880,000^{*}$ & 10,000 \\
\hline
\end{tabular}

*Signifikan pada $\alpha=5 \%$.

Selanjutnya IHK empat kota di Provinsi Sulawesi Selatan dicari keheterogenan lokasinya, keheterogenan IHK empat kota di Provinsi Sulawesi Selatan dilihat menggunakan indeks gini, nilai indeks gini untuk keempat kota sebesar 1,00 hal ini menunjukkan bahwa IHK empat kota di Provinsi Sulawesi Selatan bersifat heterogen, sehingga pemodelan menggunakan model Generalized Space Time Autoregressive (GSTAR) dapat diterapkan pada data ini.

\section{Identifikasi Model GSTAR}

Tahapan identifikasi yang perlu dilakukan sama seperti halnya dengan kasus univariat, dengan melihat apakah data IHK di empat kota sudah stasioner dalam mean dan varian.

Kestasioneritasan data dalam varian dapat dilihat melaui plot Box-Cox. Berdasarkan hasil yang diperoleh diketahui bahwa batas bawah, batas atas, rounded value, dan lambda estimate masing-masing variabelnya tidak sama. Jika dilakukan transformasi, maka transformasi yang dipakai berbeda-beda sesuai dengan lambda estimate masing-masing variabel. Oleh karena itu transformasi tidak perlu dilakukan dan data dapat dianggap stasioner dalam variansi (Shofiyah et al [8]), sehingga dalam penelitian ini pengecekan stasioneritas hanya dilakukan terhadap mean. Stasioneritas dalam mean dapat dilihat melalui plot MACF sebagai berikut:

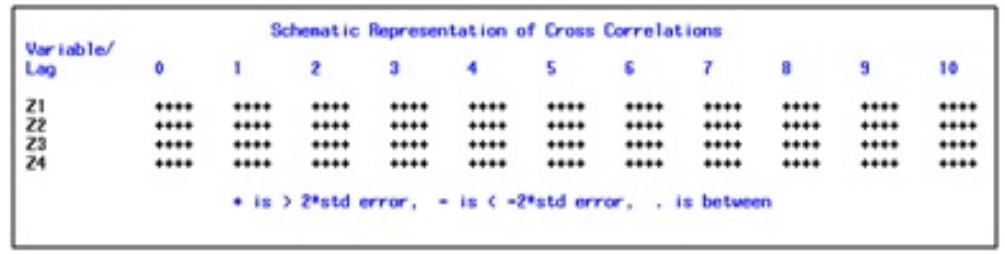

Gambar 2. MACF Data IHK di empat Kota

Terlihat pada Gambar 2 semua lag terdapat nilai korelasi yang melebihi 2 kali standar eror. Hal ini ditunjukkan oleh banyaknya simbol (+) pada MACF yang berarti secara simultan 
keempat lokasi memiliki korelasi positif, sehingga dapat dikatakan bahwa data $Z_{1(t)}, Z_{2(t)}, Z_{3(t)}$ dan $Z_{4(t)}$ tidak stasioner dalam mean dan perlu dilakukan differencing.

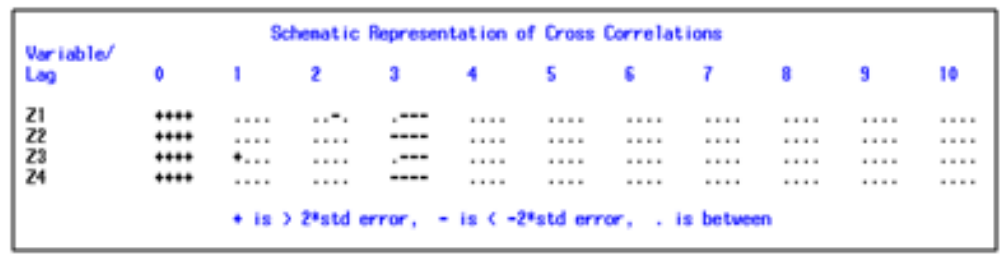

Gambar 3. MACF Data IHK di empat Kota setelah differencing 1

Gambar 3 menujukkan bahwa data sudah stasioner dalam mean. Hal ini ditunjukkan oleh banyaknya simbol (.) yang mengindikasikan bahwa tidak adanya korelasi. Sedangkan simbol (+) dan (-) pada skema hanya keluar pada lag tertentu. Kondisi ini berarti bahwa data telah stasioner setelah dilakukan differencing 1. Setelah data sudah stasioner dalam mean dan variansi, maka selanjutnya adalah mencari orde waktu model GSTAR melalui identifikasi model Vector Autoregressive (VAR). Melalui MPACF terlihat bahwa lag yang keluar melebihi \pm 2 kali standar error terdapat pada lag 1, 2 dan 3 .

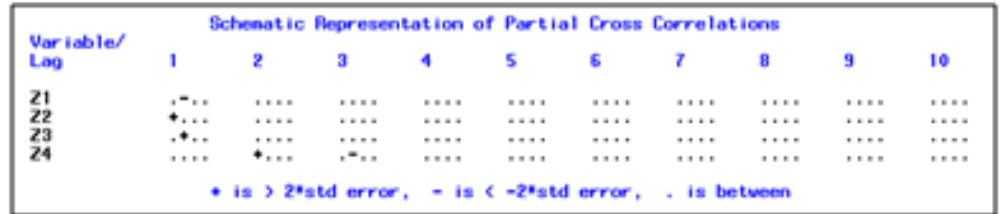

\section{Gambar 4. MPACF Data IHK di empat Kota setelah differencing 1}

Model VAR yang terbentuk dari identifikasi pada tahap ini adalah model VAR dengan orde autoregressive $(\mathrm{p})=1$ karena memiliki nilai AIC minimum yaitu $-3,277371$ terdapat pada $\mathrm{AR}=1$ seperti terlihat pada gambar 5 berikut:

\begin{tabular}{|c|c|c|c|c|c|c|}
\hline \multicolumn{7}{|c|}{ Minimum Infornation Criterion } \\
\hline Lag & $m o$ & $m 1$ & $m 2$ & $m a$ & $m_{4} 4$ & ms \\
\hline $\begin{array}{ll}A R & 0 \\
A P & 1 \\
A R & 2 \\
A P & 3 \\
A R & 4 \\
A P & 5\end{array}$ & $\begin{array}{l}-3.19312 \\
-3.277371 \\
-3.051197 \\
-2.530653 \\
-2.905051 \\
-1.424273\end{array}$ & $\begin{array}{l}-2.509041 \\
-2.436535 \\
-2.242139 \\
-1.77355 \\
=1.244735 \\
=0.550682\end{array}$ & $\begin{array}{l}-2.585467 \\
-2.334147 \\
-1.680653 \\
-1.004733 \\
-0.329092 \\
0.4460595\end{array}$ & $\begin{array}{l}-2.275395 \\
-1.942564 \\
-1.062341 \\
-0.064129 \\
0.8946214 \\
1.8345328\end{array}$ & $\begin{array}{l}-2.050683 \\
-1.377023 \\
-0.475458 \\
0.6957405 \\
2.4591183 \\
4.4098323\end{array}$ & $\begin{array}{l}-1.528231 \\
-0.500994 \\
0.5996302 \\
1.9573901 \\
4.0106544 \\
7.0863456\end{array}$ \\
\hline
\end{tabular}

Gambar 5. Ringkasan Nilai AIC dari Semua Orde Model setelah Differencing 1

Data yang digunakan merupakan data yang telah di differencing 1,orde spasial yang digunakan adalah orde spasial 1, sedangkan lag waktu yang digunakan adalah 1 yang ditentukan berdasarkan hasil identifikasi model VAR. Sehingga model GSTAR yang digunakan adalah GSTARI $(1 ; 1 ; 1)$ dan model tersebut dapat ditaksir parameternya menggunakan metode OLS.

\section{Penaksiran Parameter}

Model GSTARI dapat dipresentasikan sebagai sebuah model linear dan parameter-parameter autoregresif model dapat diestimasi menggunakan metode kuadrat terkecil atau metode least 
square. Persamaan yang digunakan untuk bobot lokasi pada model GSTARI $(1 ; 1 ; 1)$ sebagai berikut:

$$
\begin{gathered}
Z(t)=\phi_{10} Z(t-1)+\phi_{11} W^{(1)} Z(t-1)+e(t) \\
{\left[\begin{array}{l}
Z_{1}(t) \\
Z_{2}(t) \\
Z_{3}(t) \\
Z_{4}(t)
\end{array}\right]=\left[\begin{array}{cccc}
\phi_{10}^{1} & 0 & 0 & 0 \\
0 & \phi_{10}^{2} & 0 & 0 \\
0 & 0 & \phi_{10}^{3} & 0 \\
0 & 0 & 0 & \phi_{10}^{4}
\end{array}\right]\left[\begin{array}{l}
Z_{1}(t-1) \\
Z_{2}(t-1) \\
Z_{3}(t-1) \\
Z_{4}(t-1)
\end{array}\right]+\left[\begin{array}{cccc}
\phi_{11}^{1} & 0 & 0 & 0 \\
0 & \phi_{11}^{2} & 0 & 0 \\
0 & 0 & \phi_{11}^{3} & 0 \\
0 & 0 & 0 & \phi_{11}^{4}
\end{array}\right]} \\
{\left[\begin{array}{cccc}
0 & w_{12} & w_{13} & w_{14} \\
w_{21} & 0 & w_{23} & w_{24} \\
w_{31} & w_{32} & 0 & w_{34} \\
w_{41} & w_{42} & w_{43} & 0
\end{array}\right]\left[\begin{array}{l}
Z_{1}(t-1) \\
Z_{2}(t-1) \\
Z_{3}(t-1) \\
Z_{4}(t-1)
\end{array}\right]+\left[\begin{array}{c}
e_{1}(t) \\
e_{2}(t) \\
e_{3}(t) \\
e_{4}(t)
\end{array}\right]}
\end{gathered}
$$

Dari model diatas terlihat bahwa model yang diperoleh telah berubah menjadi GSTARI, hal ini dapat dilihat dari hasil differencing menjadi $Y(t)=Z(t)-Z(t-1)$.

\section{Penentuan Bobot Lokasi pada Model GSTAR}

Setelah mengidentifikasi model, selanjutnya adalah menentukan bobot lokasi untuk GSTARI $(1 ; 1 ; 1)$. Berikut keempat bobot lokasi yang digunakan dalam penelitian ini:

$$
\text { Bobot Lokasi Seragam } w_{i j}=\left[\begin{array}{cccc}
0 & 0,33 & 0,33 & 0,33 \\
0,33 & 0 & 0,33 & 0,33 \\
0,33 & 0,33 & 0 & 0,33 \\
0,33 & 0,33 & 0,33 & 0
\end{array}\right]
$$

Bobot lokasi seragam memberikan nilai bobot yang sama untuk setiap lokasi. Nilai dari bobot seragam dihitung dengan rumus $w_{i j}=\frac{1}{n_{i}}$ dengan $n_{i}$ adalah jumlah lokasi yang berdekatan dengani.

Bobot Lokasi Biner $w_{i j}=\left[\begin{array}{cccc}0 & 0 & 1 & 0 \\ 0 & 0 & 1 & 0 \\ 1 & 0 & 0 & 0 \\ 1 & 0 & 0 & 0\end{array}\right]$

Perhitungan menggunakan bobot ini hanya memberikan nilai 0 atau 1. Hubungan antara dua kota yang secara geografis berdekatan didefinisikan $w_{i j}=1$. Jika secara geografis berjauhan, maka didefinisikan $w_{i j}=0$.

$$
\text { Bobot Lokasi Invers Jarak } w_{i j}=\left[\begin{array}{cccc}
0 & 0,317 & 0,402 & 0,281 \\
0,246 & 0 & 0,532 & 0,222 \\
0,423 & 0,291 & 0 & 0,287 \\
0,456 & 0,268 & 0,277 & 0
\end{array}\right]
$$

Pembobotan dengan metode invers jarak dilakukan berdasarkan jarak antar lokasi. Lokasi yang berdekatan mendapat nilai bobot yang lebih besar. Perhitungan bobot dengan metode invers jarak diperoleh dari hasil invers jarak kemudian dinormalisasi.

$$
\text { Bobot Lokasi Normalisasi Korelasi Silang } w_{i j}=\left[\begin{array}{cccc}
0 & -1,651 & -1,065 & 1,175 \\
0,422 & 0 & 0,264 & 0,314 \\
0,382 & 0,313 & 0 & 0,305 \\
0,526 & 0,167 & 0,307 & 0
\end{array}\right]
$$

Pembobotan pada model GSTAR dengan bobot normalisasi korelasi silang dihitung berdasarkan dari nilai-nilai korelasi silang antar lokasi yang dinormalisasi pada lag waktu yang bersesuaian.

\section{Estimasi Parameter Model GSTAR}



Tabel 2.

Hasil penaksiran parameter model GSTAR dengan bobot seragam dapat dilihat pada

TABel 2. Penaksiran Parameter Bobot Seragam dengan Metode Stepwise

\begin{tabular}{cccc}
\hline Parameter & Nilai & t-hitung & P-value \\
\hline$\phi_{10}^{2}$ & 0,24 & 2,01 & $0,046 *$ \\
$\phi_{10}^{3}$ & 0,26 & 2,22 & $0,028 *$ \\
$\phi_{11}^{1}$ & 0,34 & 2,78 & $0,006 *$ \\
$\phi_{11}^{4}$ & 0,25 & 2,04 & $0,042 *$ \\
\hline
\end{tabular}

${ }^{*}$ Signifikan pada $\alpha=5 \%$.

Hasil penaksiran parameter model GSTAR dengan bobot biner dapat dilihat pada Tabel 3.

TABel 3. Penaksiran Parameter Bobot Biner dengan Metode Stepwise

\begin{tabular}{cccc}
\hline Parameter & Nilai & t-hitung & P-value \\
\hline$\phi_{10}^{3}$ & 0,71 & 3,06 & $0,002 *$ \\
$\phi_{11}^{1}$ & 0,35 & 2,99 & $0,003 *$ \\
$\phi_{11}^{2}$ & 0,28 & 2,42 & $0,016 *$ \\
$\phi_{11}^{3}$ & $-0,52$ & $-2,25$ & $0,026 *$ \\
\hline
\end{tabular}

${ }^{*}$ Signifikan pada $\alpha=5 \%$. Tabel 4.

Hasil penaksiran parameter model GSTAR dengan bobot invers jarak dapat dilihat pada

TABeL 4. Penaksiran Parameter Bobot Invers Jarak dengan Metode Stepwise

\begin{tabular}{cccc}
\hline Parameter & Nilai & t-hitung & P-value \\
\hline$\phi_{10}^{2}$ & 0,24 & 2,00 & $0,047 *$ \\
$\phi_{10}^{3}$ & 0,26 & 2,20 & $0,028 *$ \\
$\phi_{11}^{1}$ & 0,35 & 2,81 & $0,005 *$ \\
\hline
\end{tabular}

*Signifikan pada $\alpha=5 \%$.

Hasil penaksiran parameter model GSTAR dengan bobot normalisasi korelasi silang dapat dilihat pada Tabel 5 .

TABel 5. Penaksiran Parameter Bobot normalisasi korelasi silang dengan Metode Stepwise

\begin{tabular}{cccc}
\hline Parameter & Nilai & t-hitung & $P$-value \\
$\phi_{10}^{2}$ & 0,24 & 2,01 & $0,045 *$ \\
$\phi_{10}^{3}$ & 0,26 & 2,22 & $0,027 *$ \\
$\phi_{11}^{1}$ & $-0,252$ & $-3,51$ & $0,001 *$ \\
\hline
\end{tabular}

*Signifikan pada $\alpha=5 \%$.

\section{Pemodelan GSTAR dengan Berbagai Bobot Lokasi}

Model GSTARI $(1 ; 1 ; 1)$ data IHK empat kota di Provinsi Sulawesi Selatan untuk masingmasing bobot lokasi dapat dilihat pada Tabel 6 . 
TABel 6. Model GSTARI (1;1;1) Data IHK Empat Kota di Provinsi Sulawesi

Selatan Masing-masing Bobot

\begin{tabular}{|c|c|c|c|c|}
\hline Lokasi & Seragam & Biner & Inver Jarak & Normalisasi Korelasi Silang \\
\hline $\begin{array}{l}\text { Watampone } \\
\left(\hat{Z}_{1}(t)\right)\end{array}$ & $\begin{array}{c}Z_{1}(t-1)+ \\
0,11\left(Z_{2}(t-1)-Z_{2}(t-2)\right)+ \\
0,11\left(Z_{3}(t-1)-Z_{3}(t-2)\right)+ \\
0,11\left(Z_{4}(t-1)-Z_{4}(t-2)\right)+ \\
e_{1}(t)\end{array}$ & $\begin{array}{c}Z_{1}(t-1)+ \\
0,35\left(Z_{3}(t-1)-Z_{3}(t-2)\right)+ \\
e_{1}(t) \\
0,098\left(Z_{4}(t-1)-Z_{4}(t-2)\right)+ \\
e_{1}(t)\end{array}$ & $\begin{array}{c}Z_{1}(t-1)+ \\
0,111\left(Z_{2}(t-1)-Z_{2}(t-2)\right)+ \\
0,141\left(Z_{3}(t-1)-Z_{3}(t-2)\right)+ \\
0,296\left(Z_{4}(t-1)-Z_{4}(t-2)\right)+ \\
e_{1}(t)\end{array}$ & $\begin{array}{c}Z_{1}(t-1)+ \\
0,416\left(Z_{2}(t-1)-Z_{2}(t-2)\right)+ \\
0,268\left(Z_{3}(t-1)-Z_{3}(t-2)\right)-\end{array}$ \\
\hline $\begin{array}{c}\text { Makassar } \\
\left(\hat{Z}_{2}(t)\right)\end{array}$ & $\begin{array}{c}Z_{2}(t-1)+ \\
0,24\left(Z_{2}(t-1)-Z_{2}(t-2)\right)+ \\
e_{2}(t)\end{array}$ & $\begin{array}{c}Z_{2}(t-1)+ \\
0,28\left(Z_{3}(t-1)-Z_{3}(t-2)\right)+ \\
e_{2}(t)\end{array}$ & $\begin{array}{c}Z_{2}(t-1)+ \\
0,24\left(Z_{2}(t-1)-Z_{2}(t-2)\right)+ \\
e_{2}(t)\end{array}$ & $\begin{array}{c}Z_{2}(t-1)+ \\
0,24\left(Z_{2}(t-1)-Z_{2}(t-2)\right)+ \\
e_{2}(t)\end{array}$ \\
\hline $\begin{array}{l}\text { Pare-Pare } \\
\left(\hat{Z}_{3}(t)\right)\end{array}$ & $\begin{array}{c}Z_{3}(t-1)+ \\
0,26\left(Z_{3}(t-1)-Z_{3}(t-2)\right) \\
+e_{3}(t)\end{array}$ & $\begin{array}{c}Z_{3}(t-1)- \\
0,52\left(Z_{1}(t-1)-Z_{1}(t-2)\right)+ \\
e_{3}(t) \\
0,71\left(Z_{3}(t-1)-Z_{3}(t-2)\right)+ \\
e_{3}(t)\end{array}$ & $\begin{array}{c}Z_{3}(t-1)+ \\
0,26\left(Z_{3}(t-1)-Z_{3}(t-2)\right)+ \\
e_{3}(t)\end{array}$ & $\begin{array}{c}Z_{3}(t-1)+ \\
0,26\left(Z_{3}(t-1)-Z_{3}(t-2)\right)+\end{array}$ \\
\hline $\begin{array}{l}\text { Palopo } \\
\left(\hat{Z}_{4}(t)\right)\end{array}$ & $\begin{array}{c}Z_{4}(t-1)+ \\
0,08\left(Z_{1}(t-1)-Z_{1}(t-2)\right)+ \\
0,08\left(Z_{2}(t-1)-Z_{2}(t-2)\right)+ \\
0,08\left(Z_{3}(t-1)-Z_{3}(t-2)\right)+ \\
\quad e_{4}(t)\end{array}$ & $Z_{4}(t-1)+e_{4}(t)$ & $Z_{4}(t-1)+e_{4}(t)$ & $Z_{4}(t-1)+e_{4}(t)$ \\
\hline
\end{tabular}

\section{Pengujian Asumsi White Noise Residual}

Pengecekan asumsi residual yang dilakukan pada model GSTARI $(1 ; 1 ; 1)$ untuk melihat bahwa residual dari masing-masing data adalah saling independen. Model GSTARI $(1 ; 1 ; 1)$ dikatakan sesuai jika residualnya white noise. Salah satu cara untuk mengecek asumsi white noise adalah dengan menggunakan kriteria AIC minimum dari residual. Jika nilai AIC terkecil berada pada lag ke-0 maka dapat dikatakan bahwa residual dari masing-masing data saling independen. Hasil pengujian asumsi pada model GSTARI $(1 ; 1 ; 1)$ dengan menggunakan empat bobot lokasi dapat dilihat pada tabel berikut:

Tabel 7. Hasil Pengujian Asumsi White Noise Residual

\begin{tabular}{cc}
\hline Bobot & Asumsi White Noise Residual \\
\hline Seragam & Residual White Noise \\
Biner & Residual Tidak White Noise \\
Invers Jarak & Residual Tidak White Noise \\
Normalisasi Korelasi Silang & Residual Tidak White Noise \\
\hline
\end{tabular}

Berdasarkan tabel diatas, residual data yang bersifat white noise hanya dimiliki oleh bobot seragam karena nilai AIC minimum dari residual model GSTARI $(1 ; 1 ; 1)$ bobot seragam terdapat pada orde AR (0) dan MA (0).

Pemilihan Model GSTAR Terbaik

Kriteria yang digunakan dalam pemilihan model terbaik ditelusuri dari nilai RMSE pada data out sample serta uji asumsi residual.

TABEL 8. Ringkasan RMSE model GSTARI $(1 ; 1 ; 1)$ pada Setiap Bobot Lokasi

\begin{tabular}{cccccc}
\hline \multirow{2}{*}{ Jenis Bobot } & \multicolumn{4}{c}{ Lokasi } & \multirow{2}{*}{ Rata-Rata } \\
\cline { 2 - 5 } & Watampone & Makassar & Pare-Pare & Palopo & \\
\hline Seragam & 10,71 & 10,60 & 10,58 & 10,64 & 10,63 \\
Biner & 10,71 & 10,60 & 10,62 & 10,67 & 10,65 \\
Invers Jarak & 10,70 & 10,60 & 10,58 & 10,67 & 10,64 \\
Normalisasi Korelasi Silang & 10,71 & 10,60 & 10,58 & 10,67 & 10,64 \\
\hline
\end{tabular}


Berdasarkan ringkasan RMSE pada Tabel 8 dapat disimpulkan bahwa model GSTARI $(1 ; 1 ; 1)$ dengan mengunakan bobot seragam merupakan model terbaik dibandingkan dengan model menggunakan bobot lainnya, karena bobot seragam memiliki rata-rata nilai RMSE lebih kecil dari rata nilai RMSE bobot lainnya yaitu 10,63 dan hanya residual bobot seragam yang memenuhi asumsi white noise. Sehingga persamaan model permalan GSTAR yang dapat digunakan untuk meramalkan data IHK keempat kota di Provinsi Sulawesi Selatan sebagai berikut

(1) Kota Watampone

$$
\begin{aligned}
& \hat{Z}_{1}(t)=Z_{1}(t-1)+0,11\left(Z_{2}(t-1)-Z_{2}(t-2)\right)+0,11\left(Z_{3}(t-1)-Z_{3}(t-2)\right)+0,11\left(Z_{4}(t-\right. \\
& \left.1)-Z_{4}(t-2)\right)+e_{1}(t)
\end{aligned}
$$

(2) Kota Makassar

$$
\hat{Z}_{2}(t)=Z_{2}(t-1)+0,24\left(Z_{2}(t-1)-Z_{2}(t-2)\right)+e_{2}(t)
$$

(3) Kota Pare-Pare

$$
\hat{Z}_{3}(t)=Z_{3}(t-1)+0,26\left(Z_{3}(t-1)-Z_{3}(t-2)\right)+e_{3}(t)
$$

(4) Kota Palopo

$$
\begin{aligned}
& \hat{Z}_{4}(t)=Z_{4}(t-1)+0,08\left(Z_{1}(t-1)-Z_{1}(t-2)\right)+0,08\left(Z_{2}(t-1)-Z_{2}(t-2)\right)+0,08\left(Z_{3}(t-\right. \\
& \left.1)-Z_{3}(t-2)\right)+e_{4}(t)
\end{aligned}
$$

\section{Peramalan Menggunakan Model GSTAR Terbaik}

Berikut hasil ramalan data IHK 4 kota di Provinsi Sulawesi Selatan menggunakan model terbaik, GSTARI $(1 ; 1 ; 1)$ menggunakan bobot seragam:

TABel 9. Hasil Ramalan Data IHK 4 Kota di Provinsi Sulawesi Selatan Menggunakan Model GSTAR terbaik

\begin{tabular}{|c|c|c|c|c|c|}
\hline Tahun & Bulan & Watampone & Makassar & Pare-Pare & Palopo \\
\hline \multirow{7}{*}{} & Januari & 159,38 & 143,62 & 143,55 & 149,88 \\
\cline { 2 - 6 } & Februari & 96,12 & 100,33 & 99,10 & 99,22 \\
\cline { 2 - 6 } & Maret & 109,41 & 108,98 & 108,41 & 109,12 \\
\cline { 2 - 6 } & April & 109,79 & 108,94 & 108,27 & 108,87 \\
\cline { 2 - 6 } & Mei & 110,58 & 109,39 & 108,62 & 109,53 \\
\cline { 2 - 6 } & Juni & 110,87 & 108,92 & 109,00 & 109,86 \\
\cline { 2 - 6 } & Juli & 111,71 & 109,32 & 109,44 & 110,40 \\
\cline { 2 - 6 } & Agustus & 113,43 & 110,76 & 110,73 & 112,71 \\
\cline { 2 - 6 } & September & 113,07 & 111,15 & 110,96 & 112,09 \\
\cline { 2 - 6 } & Oktober & 112,79 & 111,55 & 110,90 & 111,36 \\
\cline { 2 - 6 } & November & 113,11 & 112,05 & 111,49 & 111,85 \\
\cline { 2 - 6 } & Desember & 115,15 & 113,81 & 113,99 & 113,81 \\
\hline
\end{tabular}

3.2. Pembahasan. Terdapat 4 bobot lokasi yang digunakan dalam penelitian ini yaitu bobot lokasi seragam, bobot lokasi biner, bobot lokasi invers jarak, dan bobot lokasi normalisasi korelasi silang. Bobot lokasi yang baik adalah bobot lokasi yang membentuk model dengan kesalahan ramalan terkecil.

Setelah mendapatkan model dari masing-masing bobot lokasi, selanjutnya model yang diperoleh diperiksa untuk mengetahui apakah model sudah memenuhi syarat kebaikan model atau belum. Suatu model dikatakan layak jika parameter model sudah signifikan dan residual dari model memenuhi asumsi white noise. Cek diagnosa residual dari model GSTARI $(1 ; 1 ; 1)$ untuk masing-masing model diperlihatkan pada Tabel 7 yang menunjukkan bahwa residual data yang bersifat white noise hanya dimiliki oleh bobot seragam karena nilai AIC minimum dari residual model GSTARI $(1 ; 1 ; 1)$ bobot seragam terdapat pada orde AR (0) dan MA (0).

Untuk memperoleh model GSTAR yang terbaik diantara model GSTAR keempat bobot lokasi maka dilakukan perbandingan terhadap rata-rata nilai RMSE. Dari hasil yang diperoleh 
bahwa model GSTAR dengan bobot lokasi seragam mempunyai rata-rata nilai RMSE yang lebih kecil dibandingkan dengan ketiga bobot lainnya yaitu sebesar 10,63.

Persamaan model peramalan GSTAR yang dapat digunakan dalam meramalkan data IHK keempat kota di Provinsi Sulawesi Selatan adalah model GSTAR dengan menggunakan bobot lokasi seragam karena model dengan bobot lokasi seragam memenuhi asumsi white noise residual dan memiliki nilai RMSE terkecil dibandingkan dengan bobot lokasi lainnya.

Model GSTAR merupakan model yang mampu menjelaskan keterkaitan waktu dan lokasi. Berdasarkan model GSTAR terbaik pada data IHK 4 kota di Provinsi Sulawesi Selatan dapat dianalisis bagaimana keterkaitan waktu dan lokasi sebagai berikut:

(1) Peramalan data IHK di Kota Watampone dipengaruhi oleh data IHK Kota Watampone satu bulan sebelumnya dan IHK Kota Makassar, Kota Pare-Pare dan Kota Palopo pada satu dan dua bulan sebelumnya.

(2) Peramalan data IHK di Kota Makassar dipengaruhi oleh data IHK Kota Makassar satu dan dua bulan sebelumnya.

(3) Peramalan data IHK di Kota Pare-Pare dipengaruhi oleh data IHK Kota Pare-Pare satu dan dua bulan sebelumnya.

(4) Peramalan data IHK di Kota Palopo dipengaruhi oleh data IHK Kota Palopo satu bulan sebelumnya dan IHK Kota Watampone, Kota Makassar dan Kota Pare-Pare pada satu dan dua bulan sebelumnya.

Hasil ramalan berdasarkan model GSTAR terbaik papat dilihat pada Tabel 9. Hasil ramalan yang diperoleh pada bulan Januari dan Februari berbeda cukup signifikan dengan data aktual, hal ini dikarenakan adanya perbedaan tahun dasar yang diberlakukan mulai Januari 2014. Mulai Maret 2014, hasil ramalan data IHK empat kota di Provinsi Sulawesi Selatan relatif stabil dan mendekati nilai data aktual.

\section{Simpulan}

Berdasarkan hasil dan pembahasan yang telah dilakukan sebelumnya, Model GSTAR terbaik untuk IHK empat kota di Provinsi Sulawesi Selatan adalah model GSTARI $(1 ; 1 ; 1)$ setelah differencing 1 dengan menggunakan bobot lokasi seragam. Model GSTARI $(1 ; 1 ; 1)$ setelah differencing 1 dengan menggunakan bobot lokasi seragam ini terbaik karena memenuhi asumsi white noise dengan rata-rata nilai RMSE sebesar 10,63. Sehingga model GSTAR yang diperoleh sebagai berikut:

$$
\begin{aligned}
\hat{Z}_{1}(t)= & Z_{1}(t-1)+0,11\left(Z_{2}(t-1)-Z_{2}(t-2)\right)+0,11\left(Z_{3}(t-1)-Z_{3}(t-2)\right)+ \\
& 0,11\left(Z_{4}(t-1)-Z_{4}(t-2)\right)+e_{1}(t) \\
\hat{Z}_{2}(t)= & Z_{2}(t-1)+0,24\left(Z_{2}(t-1)-Z_{2}(t-2)\right)+e_{2}(t) \\
\hat{Z}_{3}(t)= & Z_{3}(t-1)+0,26\left(Z_{3}(t-1)-Z_{3}(t-2)\right)+e_{3}(t) \\
\hat{Z}_{4}(t)= & Z_{4}(t-1)+0,08\left(Z_{1}(t-1)-Z_{1}(t-2)\right)+0,08\left(Z_{2}(t-1)-Z_{2}(t-2)\right)+ \\
& 0,08\left(Z_{3}(t-1)-Z_{3}(t-2)\right)+e_{4}(t)
\end{aligned}
$$

Hasil ramalan yang diperoleh pada bulan Januari dan Februari berbeda dengan data aktual, hal ini dikarenakan adanya perbedaan tahun dasar yang diberlakukan mulai Januari 2014, sehingga IHK yang diperoleh pada bulan Januari dan Februari berpengaruh terhadap perubahan harga. Mulai Maret 2014, hasil ramalan data IHK empat kota di Provinsi Sulawesi Selatan relatif stabil dan mendekati nilai data aktual.

\section{DAFtar Pustaka}

[1] BPS, 2015, Laporan Perekonomian Indonesia 2015, Badan Pusat Statistik, Jakarta.

[2] BPS, 2015, Indeks Harga Konsumen 82 Kota Di Indonesia $(2012=100)$ 2015, Badan Pusat Statistik, Jakarta. 
[3] Kemenko Perekonomian, 2015, Tinjauan Ekonomi \& Keuangan, Kementrian Koordinator Bidang Perekonomian, Jakarta.

[4] Hapsari, R., 2017, Pengembangan Ramalan Interval Pada Model Gstarx Untuk Peramalan Indeks Harga Konsumen Kelompok Bahan Makanan, Tesis, Fakultas Matematika Dan Ilmu Pengetahuan Alam, Institut Teknologi Sepuluh Nopember, Surabaya. Http://Repository.Its.Ac.Id/3056/

[5] Ardianto, M.P., 2014, Pemodelan Generalized Space Time Autoregressive (GSTAR) pada Tiga Periode Waktu (Studi Kasus Inflasi di Lima Kota Besar di Pulau Jawa), Jurnal Mahasiswa Statistik, Vol. 2 No. 4: pp. 265-268.

[6] Ruchjana, B.N., 2002, Suatu Model Generalisasi Space-Time Autoregresi dan Penerapannya pada Data Produksi Minyak Bumi, Disertasi, Tidak Dipublikasikan, Program Pascasarjana, Bandung: Institut Teknologi Bandung.

[7] Borovkova, S.A., Lopuha, H.P., and Ruchjana, B.N., 2008, Consistency and Asymtotic Normality of Least Squares Estimators in Generalized STAR Models, Statistica Neerlandica, Vol.62, 482-508.

[8] Shofiyah, M.A., 2009, Peramalan Data Produksi Gas di Joint Oper ating Body Pertamina-Petrochina East Java (JOB P-PEJ) dengan Model GSTAR dan ARIMA. . 
